\title{
PENGARUH KLASTER KERAJINAN ENCENG GONDOK KLINTING TERHADAP SUMBER DAYA MANUSIA SEKITAR RAWA PENING
}

\author{
Arfiati Nurul Komariah \\ Jurusan Pengkajian Seni Kriya Kulit, Fakultas Penciptaan dan Pengkajian Seni \\ Pascasarjana Institut Seni Indonesia Yogyakarta \\ e-mail :pps_isiyk@yahoo.com \\ Diterima : 6 Maret 2019. Disetujui : 9 Mei 2019. Dipublikasikan : 30 Juni 2019

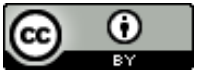 \\ (O2019 - DESKOVI Universitas Maarif Hasyim Latif. Ini adalah artikel dengan akses \\ terbuka di bawah lisensi CC BY 4.0 (https://creativecommons.org/licenses/by/4.0/)
}

\begin{abstract}
ABSTRAK
Penelitian ini bertujuan untuk mengetahui seberapa jauh ketertarikan masyarakat terhadap kerajinan enceng gondok, terutama bagi masyarakat sekitar Rawa Pening, serta guna memberikan wawasan kepada masyarakat umum bahwa enceng gondok yang selama ini dianggap sebagai gulma itu dapat di eksplorasi dan di eksploitasi menjadi bahan baku kerajinan tangan yang bernilai jual tinggi. Kemudian dalam penelitian ini penulis menggunakan metode penelitian kualitatif deskriptif, melalui pendekatan etnografi sebagai cara untuk menguraikan suatu sistem kelompok sosial dan mempelajari pola perilaku kebiasaan dan cara hidup. Sehingga hasil yang didapatkan dari penelitian ini adalah untuk mengetahui peluang dan pengaruh apa yang dirasakan oleh masyarakat sekitar Rawa Pening, dengan adanya Klaster Kerajinan Enceng Gondok "Klinting". Karena dari penelitian ini juga dapat diketahui bahwa masyarakat sekitar Rawa Pening dapat menambah penghasilan dan dapat mengurangi adanya dampak buruk dari adanya gulma perairan.
\end{abstract}

Kata kunci: Klaster Kerajinan Enceng Gondok, Pengaruh, Sumber Daya Manusia

\begin{abstract}
This research have purpose to know how far the society toward water hyacinth handicraft especially to Rawa Pening society, and to give a knowledgement to people that water hyacinth all this time known as a weeds could be expoloration and exploitation to be handicraft maertail who have a high value. And then, for other in this research the researcher used qualitative descriptive method, by phenomenological ethnography as mode to analyze social category system and learned behavior pattern of way of living. With the result that from the research was to known the opportunity and the influences of society in Rawa Pening, with this klaster of water hyacinth handycraft "KLINTING". Therefore, this research was to known that society of Rawa Pening got increased their income and decreased the negative impact of water hyacinth
\end{abstract}

Keyword: Klaster of Water Hyacinth Handycraft, Influence, Human Resources.

\section{PENDAHULUAN}

Keanekaragaman hasil produk kerajinan Indonesia merupakan salah satu wujud karya manusia yang mewarnai khasanah kebudayaan nasional. Latar belakang sosial budaya yang berbeda dari masingmasing etnis, tercermin kedalam kerajinan yang meliliki ciri khusus. Seperti sebuah ruang atau bidang yang merupakan wadah bagi penempatan benda hias yang telah diciptakan. Pekriya tersebut mengubah benda-benda asalan dengan cara garap dan dengan desain tertentu, sehingga menjadi berang-barang berfungsi estetika dan etik. Hasil yang didapatkan berupa benda seni, komoditi, serta hasil budaya yang semuanya terkandung dalam kehidupan keseharian.

Indonesia merupakan negara yang kaya akan sumber daya alamnya. Sumber daya alam tersebut meliputi hutan yang luas, pertanian, peternakan, hasil tambang, dan hasil laut. Salah satu dari sumber daya alam tersebut adalah enceng gondok. Enceng gondok (echhornia crassipes) termasuk dalam kelompok gulma perairan. Daunnya berbentuk bulat telur dan berwarna hijau segar serta daun-daun tersebut dipotong oleh tangkai berbentuk silinder memanjang yang kadangkadang sampai mencapai satu meter dengan diameter satu sampai dua $\mathrm{cm}$ (sentimeter) (Kaleka, 2014: 3).

Satu batang enceng gondok dalam waktu 52 hari mampu menghasilkan tanaman baru seluas satu $\mathrm{m} 2$ (meter persegi). Bisa dibayangkan, selama 106 tahun berada di bumi Indonesia enceng gondok hampir menyebar ke seluruh perairan yang ada dan memenuhi setiap jengkalnya, baik waduk, rawa, danau, maupun sungai dimanapun keberadaannya. Berbagai gangguan yang ditimbulkan sudah cukup mencemaskan, namun ironisnya, hingga sekarang belum ditemukan cara yang optimal untuk memberantasnya. 
Enceng gondok yang berkembang di Rawa Pening juga merupakan salah satu objek wisata di Ambarawa Kabupaten Semarang Jawa Tengah saat ini telah mencapai jumlah yang sangat banyak. Permukaan air Rawa Pening yang berkisat 7.200 hektar, 6.000 hektar diantaranya tertutup enceng gondok (Haryono, 2014: 1). Tertutupnya permukaan perairan menyebabkan berkurangnya jenis binatang air dan pendapatan petani serta pengunjung wisata daerah tersebut.

Meskipun cukup merepotkan, keberadaan enceng gondok dapat juga bermanfaat secara komersial. Tak seorang pun dapat menduga sebelumnya, bahwa usaha pemerintah yang habishabisan untuk membasmi enceng gondok yang belum mencapai hasil yang optimal justru membuahkan penemuan baru yang dapat dimanfaatkan untuk mendapatkan tambahan penghasilan dari penggunaan enceng gondok. Batang enceng gondok dapat dijadikan sebagai bahan baku produk kerajinan anyaman yang dapat dikomersialkan. Enceng gondok di Rawa Pening tersedia dalam jumlah yang sangat besar, namun belum banyak perajin atau pengusaha kerajinan yang memanfaatkannya. Kerajinan enceng gondok merupakan kerajinan yang unik, karena selama ini enceng gondok dianggap sebagai gulma atau hama perairan, namun ternyata dapat berubah menjadi komoditi usaha yang menjanjikan jika diolah menjadi berbagai jenis kerajinan yang menarik, berseri dan berdaya jual tinggi.

Pada penelitian ini, penulis ingin melakukan observasi terhadap salah satu Klaster Kerajinan Enceng Gondok "Klinting” di Dusun Donosari, Desa Tegaron, Kecamatan Banyubiru, Kabupaten Semarang, Jawa Tengah. Enceng gondok di Rawa Pening tersedia dalam jumlah yang sangat besar, namun belum banyak perajin atau pengusaha kerajinan yang memanfaatkannya. Kerajinan enceng gondok merupakan kerajinan yang unik, karena selama ini enceng gondok dianggap sebagai gulma atau hama diperairan, namun ternyata dapat berubah menjadi komoditi usaha yang menjanjikan jika diolah menjadi berbagai jenis kerajinan yang menarik dan berdaya jual tinggi. Kemudian dari hal tersebut banyak masyarakat yang akhirnya diajak untuk berpartisipasi dalam setiap acara yang berhubungan dengan Klaster Kerajinan Enceng Gondok "Klinting".

Tujuan penelitian ini adalah untuk memperoleh jawaban atas pengaruh Klaster Kerajinan Enceng Gondok "Klinting" terhadap sumber daya manusia di sekitar Rawa Pening. Ingin mengetahui seberapa jauh ketertarikan masyarakat terhadap kerajinan enceng gondok, terutama bagi masyarakat di sekitar Rawa Pening. Guna memberikan wawasan kepada masyarakat umum bahwa enceng gondok yang selama ini dianggap sebagai gulma, dapat di eksplorasi dan di eksploitasi menjadi bahan baku kerajinan tangan yang bernilai jual tinggi dan mengimplementasi pengetahuan dan keterampilan dalam bidang kerajinan tangan, terutama yang berbahan dasar enceng gondok.
Tinjauan pustaka merupakan sumber acuan yang berhubungan dengan tema yang diawali dengan studi kepustakaan untuk mendapatkan data. Terdapat beberapa acuan yang diambil dari media cetak dan media elektronik yang digunakan untuk dijadikan referensi dan sumber acuan dalam melandasi suatu penelitian.

Baik buku, jurnal maupun artikel yang dapat dijadikan sebagai pedoman dalam penelitian, secara umum telaah pustaka bersumber dari beberapa buku, jurnal maupun artikel yang dianggap dapat mendukung dalam penelitian tersebut. Kemudian terdapat beberapa penelitian yang berhubungan dengan teori dan pengetahuan kerajinan enceng gondok, sumber daya manusia, dan manajemen.

Enceng gondok (Eicornia Crassipes) merupakan tumbuhan air mengapung, karena memiliki batang yang tebal dan bergelembung yang berkembang biak sangat cepat sehingga dapat merusak lingkungan perairan. Anggapan negatif lainnya tentang enceng gondok adalah bahwa tanaman tersebut dapat menjadi salah satu penyebab banjir. Oleh sebab itu, batang enceng gondok akan digunakan sebagai bahan baku pembuatan kerajinan tangan.

Kerajinan menurut Kadjim adalah sesuatu usaha yang dilakukan secara terus menerus dengan penuh semangat ketekunan, kecermatan, kegigihan, berdedikasi tinggi, dan berdaya maju yang luas dalam melakukan suatu karya. Selain itu, produk kerajinan tangan juga pasti mempunyai harga tinggi, maka dari itu sudah sepatutnya sebagai warga negara kita harus mampu menciptakan sebuah kerajinan, atau paling tidak produk kerajinan asli Indonesia.

Kemudian dari pengertian kerajinan tersebut terbitlah beberapa buku mengenai kerajinan tangan, salah satunya buku Nobertus Kaleka yang berjudul Kerajinan Enceng Gondok, 2014. Buku ini mengupas tentang pengertian enceng gondok, dampak negatif dan positif yang dihasilkan dari tanaman enceng gondok, serta cara penanggulangannya dengan cara memanfaatkan batang enceng gondok untuk dijadikan kerajinan tangan yang dapat dikomersialkan. Kemudian terdapat contoh proses pembuatan kerajinan mulai dari memanen sampai dengan finishing barang jadi.

Sumber daya manusia merupakan faktor penting dalam suatu organisasi atau perusahaan. Agar aktivitas manajemen berjalan dengan baik, maka perusahaan harus memiliki karyawan yang berpengetahuan dan berketerampilan inggi serta usaha untuk mengelola perusahaan seoptimal mungkin sehingga kinerja karyawan meningkat.

Menurut Syamsudinnor (2014: 2), sumber daya manusia merupakan salah satu modal utama dalam suatu organisasi, dimana dapat memeberikan kontribusi yang tidak ternila dalam strategi pencapaian tujuan organisasi. Salah satu contoh pentingnya kontribusi sumber daya manusia dalam sebuah perusahaan dapat dilihat dari proses produksi. Dimana ketika perusahaantersebut sudah memiliki finansial yang kuat, 
bahan baku yang terpenugi, dan teknologi terbaru namun tidak adanya sumber daya manusia yang baik, maka proses roduksi tidak akan berjalan lancar.

\section{METODE PENELITIAN}

\section{Pengumpulan Data}

Penelitian ini merupakan penelitian kualitatif yang berusaha memberikan gambaran terhadap keadaan yang terjadi, atau dikenal dengan penelitian deskriptif. Penelitian deskriptif adalah penelitian yang memberikan gambaran secara sistematis mengenai fakta-fakta atau karakteristik populasi tertentu secara faktual dan cermat (Rahmat, 2004: 25).

Berdasarkan permasalahan yang diajukan mengenai pengaruh klaster kerajianan enceng gondok "KLINTING" terhadap sumber daya manusia sekitar Rawa Pening, maka penelitian ini menggunakan metode etnografi. Metode etnografi adalah uraian dan penafsiran suatu budaya atau sistem kelompok sosial. Peneliti menguji kelompok tersebut dan mempelajari pola perilaku kebiasaan dan cara hidup. Etnografi adalah sebuah proses dan hasil dari sebuah penelitian. Sebagai proses, etnografi melibatkan pengamatan yang cukup panjang terhadap suatu kelompok, dimana dalam pengamatan tersebut penulis terlibat dalam keseharian hidup responden melalui wawancara satu per satu dengan anggota kelompok tersebut. Penulis mempelajari arti atau makna dari setiap perilaku, bahasa dan interaksi dalam kelompok.

Sumber data dalam penelitian kualitatif terdiri dari beberapa jenis, dapat berupa orang, peristiwa, tempat atau lokasi, benda, dan dokumen atau arsip. Beragam sumber data tersebut menuntut cara atau teknik pengumpulan data tertentu yang sesuai guna mendapatkan data yang diperlukan untuk menjawab permasalahannya. Adapun strategi pengumpulan data dalam penelitian kualitatif yang dilakukan pada penelitian ini adalah sebagai berikut:

\section{a. Alasan pemilihan kasus}

Pemilihan kasus pada penelitian ini mengenai pengaruh Klaster Kerajinan Enceng Gondok "Klinting" terhadap sumber daya manusia di sekitar Rawa Pening, Kab. Semarang. Penulis ingin melakukan observasi terhadap salah satu perusahaan yang berkecimpung dalam usaha kerajinan tangan dengan bahan baku dari batang enceng gondok. Kemudian dari pada itu, penulis juga ingin mengembangkan kerajinan enceng gondok tersebut di kota asal yaitu Palembang. Karena di Palembang juga terdapat banyak tanaman enceng gondok, namun belum banyak masyarakat yang mengetahui manfaatnya.

\section{b. Alasan pemilihan tempat}

Tanaman enceng gondok mempunyai kemampuan yang sangat besar untuk menyesuaikan diri terhadap perubahan keadaan lingkungan. Salah satu hal yang membuat enceng gondok memiliki kecepatan berkembang biak yang sangat tinggi, terutama di daerah tropis dan subtropis. Tanaman ini biasa ditemukan ditempat-tempat yang sering tergenang air, seperti rawa, sungai atau area persawahan di daratan rendah yang biasanya tidak pernah kering. Salah satu contoh daerah yang sangat berlimpah yaitu daerah Sungai Musi di Kota Palembang, Sumatera Selatan. Di daerah ini terdapat banyak sekali tanaman enceng gondok yang belum dimanfaatkan sebagai bahan baku produk kerajinan yang dapat diperjual belikan.

Berdasarkan hal di atas, maka penulis ingin melakukan observasi secara mendalam mengenai tanaman enceng gondok serta proses pengolahan kerajinannya. Kemudian penulis juga ingin mencoba mencari tahu pengaruh atau dampak apa yang ditimbulkan oleh salah satu Klaster di Kabupaten Semarang terhadap sumber daya manusia sekitar Rawa Pening dan permasalahan yang beredar di masyarakat Palembang tentang adanya anggapan negatif mengenai gulma perairan tersebut. Perusahaan Klaster Kerajinan Enceng Gondok "Klinting” dipilih sebagai tempat yang tepat karena memiliki beberapa faktor antara lain: menyediakan informasi mengenai tanaman enceng gondok yang berda di Rawa Pening dan macam-macam kerajinannya seperti sandal, tas, miniatur becak, kotak tisu, lukisan dan masih banyak lagi. Untuk pemasaran produk di Klaster Kerajinan Enceng Gondok "Klinting" menggunakan sistem secara online, pameran, dan reseller, sedangkan pada bagian manajemen terbagi menjadi dua yaitu manajemen perkelompok dan manajemen dari keseluruhan kelompok. Maka dengan cara inilah masyarakat mendapatkan penghasilan tambahan. Selain itu juga untuk mengeksplorasi dan mengeksploitasi gulma yang terdapat di Rawa Pening. Karena pada umumnya kerajinan yang terdapat di Indonesia hanya sedikit yang memanfaatkan tanaman enceng gondok ini, mereka kebanyakan menggunakan serat alam dari daun pandan, pelepah pisang, rotan dan lain sebagainya.

\section{c. Metode pengumpulan data}

Untuk melakukan penelitian, penulis menggunakan beberapa teknik observasi. Pertama, observasi berperan pasif guna menggali data dari sumber berupa peristiwa, tempat atau lokasi, benda, serta rekaman gambar. Guna menjaga reliabilitas studi, observasi yang dilakukan oleh penulis tidak hanya sekali. Dalam observasi ini penulis mendatangi lokasi dan melakukan beberapa tahap wawancara, tetapi sama sekali tidak berperan sebagai apapun selain sebagai peneliti yang berperan pasif. Kedua, observasi berperan aktif guna mengetahui proses produksi dari kerajinan enceng gondok.

Kemudian pada saat penulis melakukan observasi, tentunya beragam gambar mengenai pekerjaan para perajin yang terlibat dalam suatu kegiatan. Maka hal tersebut bisa menjadi sumber data yang penting untuk dimanfaatkan dalam penelitian beserta data yang didapatkan dari wawancara. 


\section{d. Teknik observasi}

Teknik yang digunakan penulis untuk mengumpulkan data dalam penelitian ini dilakukan kurang lebih selama satu bulan. Observasi yang pertama penulis lakukan adalah observasi mengenai tahap awal untuk merumuskan panduan pengamatan terhadap beberapa perajin di Klaster Kerajinan Enceng Gondok "Klinting", karena terdapat tujuh kelompok berbeda dalam satu organisasi. Kemudian pengamatan yang selanjutnya adalah pengamatan lapangan yang terfokus untuk mengumpulkan data tentang sejarah singkat Rawa Pening, proses pembuatan kerajinan enceng gondok, pembagian kerja para perajin, sampai dengan pengaruh Klaster Kerajinan Enceng Gondok "Klinting" terhadap sumber daya manusia di sekitar Rawa Pening. Observasi yang dilakukan oleh penulis kurang lebih enam jam dalam sehari, pada pagi hari penulis memakan waktu kurang lebih dua jam untuk berkunjung ke Rawa Pening untuk melihat petani memanen enceng gondok dan sesekali penulis ikut memanen, kemudian pada siang hari penulis berkunjung ke pengepul-pengepul enceng gondok yang berbeda, dan pada malam hari penulis diajarkan oleh ketua Klaster untuk membuat kerajinan enceng gondok.

Selain itu, penulis juga melakukan teknik pencatatan dan dokumentasi berupa foto para perajin yang sedang bekerja. Catatan lapangan tersebut awalnya hanya dibuat seperti poin-poin yang menurut penulis penting, kemudian pada saat di di kos, catatan tersebut di jabarkan lebih mendetail lagi dan dikaitkankan dengan data yang didapatkan dari hasil wawancara, apakah telah sesuai dengan apa yang telah dirumuskan sebelumnya.

\section{Analisis Data}

Komponen utama untuk menganalisis data yaitu dengan reduksi data atau proses seleksi, pemfokusan, penyederhanaan, dan abstraksi data dari fieldnote. Biasanya proses ini dilakukan sebelum pelaksanaan pengumpulan data. Artinya, reduksi data sudah berlangsung sejak peneliti mengambil keputusan walaupun tidak disadari sepenuhnya, tentang kerangka kerja konseptual, melakukan pemilihan kasus, menyusun pertanyaan penelitian, dan juga waktu menentukan cara pengumpulan data yang akan digunakan (Sutopo, 2001: 91).

Setelah mengetahui teknik observasi yang dilakukan, maka tahap selanjutnya yaitu menganalisis data tersebut. Catatan hasil lapangan yang berupa poinpoin tadi kemudian dijabarkan menjadi sebuah catatan yang mendetail. Catatan lapangan ditulis bersamaan dengan hari, tanggal, bulan, tahun, dan dimulai dari pukul berapa hingga pukul berapa.

\section{PEMBAHASAN}

\section{Nama Lokasi}

Perusahaan Klaster Kerajianan Enceng Gondok "Klinting" dipilih oleh penulis sebagai salah satu tempat observasi yang tepat untuk penelitian ini. Lokasi perusahaan ini beralamat di Dusun Donosari, RT. 004, RW. 003, Desa Tegaron, Kecamatan Banyubiru, Kabupaten Semarang, Jawa Tengah. Daerah ini terdapat banyak objek wisata salah satunya Rawa Pening. Rawa Pening menjadi sumber mata pencaharian masyarakat sekitar karena salah satu budidaya tanaman enceng gondoknya. Tempat tersebut tidak berada di pusat kota, melainkan berada di sebuah desa. Namun, ditempat ini sering didatangi oleh mahasiswa yang ingin melakukan penelitian tentang enceng gondok dan kuliah kerja nyata di daerah tersebut atau banyak atau banyak pengunjung yang datang hanya sekedar untuk berwisata saja.

Danau Rawa Pening terbentang luas kurang lebih 7.200 hektar, terdapat di antara jajaran Gunung Merbabu, Gunung Telomoyo, Gunung Kendil, dan Bukit Cinta. Rawa Pening berada di Kecamatan Banyubiru, Ambarawa, Kabupaten Semarang, Jawa Tengah. Untuk menuju ke Rawa Pening ada beberapa rute yang dapat ditempuh yakni melalui Bandungan, Magelang, dan Salatiga. Jika dari Bandungan dan Magelang melewati jalur ke arah Ambarawa atau Banyubiru Raya. Sedangkan dari arah Salatiga pengunjung dapat menggunakan jalur alternative Salatiga, nanti akan ada petunjuk arah menuju Ambarawa, ikuti jalan tersebut kurang lebih $9 \mathrm{~km}$ (kilometer) atau sekitar 20 menit. Transportasi yang dapat digunakan seperti kendaraan pribadi ataupun angkutan umum seperti angkot yang berwarna kuning.

Perusahaan yang terdapat nama "Klinting" ini awalnya diambil dari legenda Baru Klinting. Istilah "klinting" diambil dari sebuah kalung yang memiliki bunyi klenting klenting, sedangkan kata "baru" artinya sesuatu benda yang baru. Legenda Baru Klinting merupakan mitos turun-temurun yang diwariskan menjadi sebuah kearifal local. Awal mula Rawa Pening dimulai pada zaman dahulu di Desa Ngasem, hidup seorang gadis bernama Endang Sawitri. Penduduk desa tidak menyadari jika Endang Sawitri belum memiliki suami, namun Endang Sawitri telah memiliki seorang anak yang dilahirkan saat dia bertapa. Endang melahirkan bayi berwujud Naga, anehnya naga itu dapat berbicara seperti halnya manusia dan naga tersebut diberi nama Baru Klinting.

Seperti biasa, setiap setahun sekali penduduk desa Pathok mengadakan pesta sedekah bumi setelah panen usai. Mereka akan mengadakan pertunjukan taritarian. Guna memeriahkan pesta rakyat itu kemudian warga pergi ke hutan untuk mencari hewan, namun tidak mendapatkan seekor hewanpun. Namun pada akhirnya mereka menemukan seekor naga besar yang merupakan ayah dari Baru Klinting yang sedang bertapa di gunung Telomoyo dan masyarakatpun langsung memotong-motong dagingnya unuk hidangan pesta. Pada saat pesta datang seorang anak kecil yang penuh luka disekujur tubuhnya, anak kecil tersebut merupakan jelmaan Baru Klinting. Baru Klinting ikut dalam keramaian itu dan ingin meminta hidangan, tetapi sikap warga yang tidak memperdulikannya. 
Bersyukur masih ada seorang nenek yang baik hati mengajaknya ke rumah untuk memberinya makanan. Anak itu berpesan jika terdengar suara gemuruh, nenek harus siapkan lesung untuk menyelamatkan diri. Sesaat kemudian, anak itu datang kembali ke pesta dengan kemarahan hati dan anak itu mengadakan sayembara. Baru Klinting pun menancapkan lidi ketanah dan berkata "barang siapa yang dapat mencabutnya dialah yang menang", namun tak seorangpun yang dapat mencabut lidi tersebut. Akhirnya Baru Klinting itu sendiri yang dapat mencabutnya, ternyata setelah lidi itu tercabut muncul air yang deras dan semakin besar. Sehingga semua warga penduduk desa tenggelam kecuali nenek tua yang menaiki lesung. Genangan air pun semakin meluas dan menjadi sebuah danau yang jernih airnya yang disebut dengan Rawa Pening (Chomsah, wawancara, 20 Maret 2018).

\section{Riwayat Singkat Perusahaan}

Klaster Kerajinan Enceng Gondok "Klinting" ini merupakan komunitas perajin enceng gondok dari Kabupaten Semarang, yang memiliki anggota 7 kelompok yaitu kelompok Sekar Melati, I Boni, Aliya, Syarina Production, Renita, Production, dan Wirakarya. Perajin dengan kreasi produk kerajinan yang diproduksi seperti sandal, lukisan, tempat tisu, pot bunga, tempat file, tas tenun, miniatur becak, miniatur tank, toples makanan, tempat air, aksesoris, tempat cincin, kotak air, hiasan kaca, dan masih banyak lagi, bahkan hingga ratusan jenis produk berbahan enceng gondok.

Pada awalnya, Klaster Kerajinan Enceng Gondok "Klinting" terbentuk atas dasar kelompok yang dipimpin oleh Slamet Triamanto, namun kelompok ini mempunyai kendala pada sumber daya manusia (SDM), meskipun untuk bahan baku enceng gondok sendiri banyak terdapat di Rawa Pening. Kemudian Slamet Triamanto dating ke kantor Dinas Perindustrian kota Semarang untuk mencari informasi tentang bagaimana cara mengembangkan Klaster Kerajinan Encneg Gondok di sekitar Rawa Pening. Akhirnya Dinas Perindustrian Kota Semarang bekerja sama dengan BAPPEDA (Badan Perencana Pembangunan Daerah) dan FEDEP (Forum Economic Development and Employment Promotion) untuk membahas bagaimana cara mengumpulkan masyarakat masyarakat agar mau mengikuti pelatihan kerajinan enceng gondok di kantor FEDEP pada tahun 2008, yang saat itu diketuai oleh Ma'ruf (almarhum) dan BAPPEDA diketuai oleh Yudi. Saat pelatihan tersebut hanya diikuti oleh tiga kecamatan yang berasal dari Kabupaten Semarang saja yaitu dari Kecamatan Tuntang, Kecamatan Banyubiru, dan Kecamatan Bawen. Didalam pelatihan FEDEP barulah pertama kali dibentuk kelompok dengan nama Paguyuban IKRASANING (Ikatan Perajin Sekitar Rawa Pening). Selanjutnya, pertemuan yang kedua dilaksanakan di Bukit Cinta dan yang memfasilitasi seorang pegawai dari BAPPEDA yang bernama Yana, pada pertemuan yang kedua ini akhirnya terbentuklah Klaster Kerajinan
Enceng Gondok "Klinting" dengan nama ketua Budiman pada tahun 2010. Karena tidak ada kegiatan sama sekali pada tahun 2010, maka Klaster Kerajinan Enceng Gondok "Klinting", akhirnya fakum. Sampai terbentuk lagi sebuah organisasi baru pada 20 April 2013 yang didampingi oleh GIZ (Gesellschaft fur Internationale Zusammenarbeit). GIZ merupakan nama sebuah perusahaan di Inggris yang memiliki beberapa cabang di Indonesia.

\section{Struktur Organisasi}

Struktur organisasi adalah suatu susunan dan hubungan antara tiap bagian serta posisi yang ada pada suatu organisasi dalam menjalankan kegiatan operasional untuk mencapai tujuan yang telah ditetapkan. Struktur organisasi bagi sebuah perusahaan sangat diperlukan, karena organisasi tersebut yang dapat mengatur pekerjaan mereka dan apa saja yang harus dilakukan guna menjamin manajemen yang efektif. Struktur organisasi menggambarkan dengan jelas bagaimana seorang pemimpin mampu merancang organisasi sehingga mampu menentukan harapanharapan mengenai apa yang akan dilakukan individuindividu dan kelompok-kelompok tersebut dalam mencapai tujuan-tujuan organisasi (Ivancevich, 2007: 235).

Disebuah perusahaan besar maupun kecil, struktur organisasi sangat penting fungsinya, guna mengatur jalan kerja suatu perusahaan tersebut. Struktur organisasi di Klaster Kerajian Enceng gondok "Klaster" menggunakan struktur organisasi fungsional. Setiap pegawai mempunyai pengawas lebih dari satu orang atasan yang berbeda-beda, karena pada perusahaan ini terbagi menjadi 7 kelompok dan pada setiap kelompok memiiki ketua masing-masing. Pimpinan atau ketua bertanggung jawab atas semua proses yang berjalan pada perusahaan tersebut. Baik itu quality control pada sumber daya manusia, bahan baku, produk, serta pemasaran. Adapun untuk pengaturan keuangan dan penggajian, dilakukan oleh bendahara perusahaan. Bagian produksi dibagi menjadi beberapa unit kerja, terkait dengan keahlian masing-masing. Tujuan dibuat struktur seperti ini, agar seluruh unit dapat berjalan sesuai dengan yang diharapkan.

Adapun struktur organisasi yang digunakan di Klaster Kerajinan Enceng Gondok "Klinting" sebagai berikut:

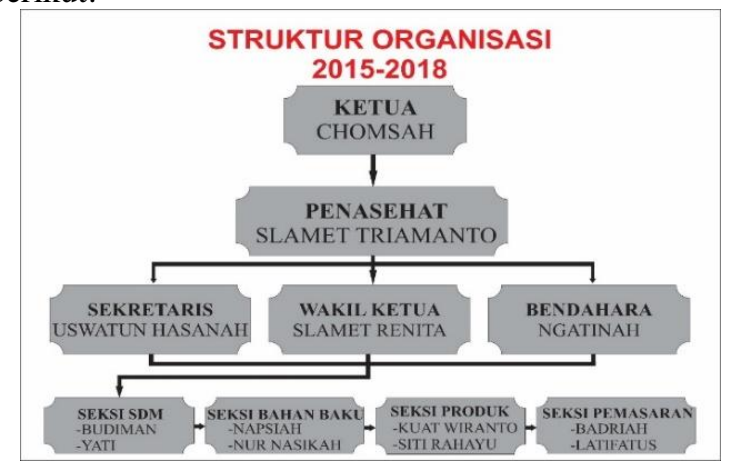

Gambar 1. Skema struktur organisasi klaster kerajinan enceng gondok "klinting" 
Pembagian tugas berdasarkan struktur organisasi yaitu:

1. Ketua merupakan orang yang memimpin dari satu bidang atau unit perusahaan yang bertanggung jawab penuh pada bagian yang dipimpinnya. Ketua pada perusahaan Klaster Kerajinan Enceng Gondok "Klinting" ini merupakan ketua pada kelompok sekar melati juga di Desa Donosari.

2. Penasehat pada perusahaan ini bertanggung jawab untuk mengarahkan dan mendampingi seluruh bagian organisasi perusahaan, karena bisnis seringkali tidak dapat berjalan dengan baik tanpa adanya penasehat.

3. Wakil Ketua perusahaan bertugas untuk membantu ketua dalam bidang apapun, sehingga di dalam sebuah perusahaan dapat tertata rapi dalam hal pekerjaan yang sudah dijadwalkan atau baru direncanakan.

4. Sekretaris mengatur semua administrasi yang berlangsung dalam perusahaan tersebut, semua yang berkaitan tentang surat masuk dan keluar, serta pengumpulan arsip penting di perusahaan merupakan tanggung jawab dari sekretaris.

5. Bendahara yaitu mengatur tentang keuangan perusahaan tersebut baik keuangan yang masuk dalam perusahaan serta yang keluar. Dalam hal tersebut bendahara juga bertanggung jawab dalam mengatur keuangan untuk gaji pegawai, perawatan alat dan juga pembelian bahan baku.

6. Seksi Sumber Daya Manusia yang mengambil alih penting dalam mengatasi kurangnya ketersediaan lapangan pekerjaan. Karena usaha ini merupakan teknologi sederhana, dengan kemauan dan semangat siapapun dapat melakukannya. Didalam mencari dan menyiapkan SDM untuk pembagian beberapa bidang tenaga kerja. Banyak tenaga usia produktif yang belum mendapatkan kesempatan kerja, potensi tenaga usia produktif ini menjadi salah satu modal pengembangan usaha ini.

7. Seksi Bahan Baku bertanggung jawab pada bagian kualitas batang enceng gondok yang di panen dan dari proses membersihkan, pengeringan, pengawetan hingga pemutihan batang enceng gondoknya.

8. Seksi Produk yang mengatasi kegiatan produksi berlangsung secara lancar dan efisien dalam memenuhi target produksi yang telah ditetapkan oleh perusahaan.

9. Seksi Pemasaran bertugas memasarkan hasil produksi dan mencari konsumen baru untuk memperluas penjualan. Biasanya pemasaran dilakukan dengan cara mengikuti pameran-pameran kerajinan atau ditempatkan pada toko-toko kerajinan.

\section{Tenaga Kerja}

Tenaga kerja yang bekerja di Klaster berasal dari penduduk Kabupaten Semarang yang dianggap dapat bekerja dan yang mampu mengerjakan jika ada order pemesanan, kualitas sumber daya manusia dapat dilihat dari hasil produksi. Tenaga kerja disini juga dapat diartikan suatu keahlian atau keterampilan yang dimiliki seseorang. Tenaga kerja di Klaster Kerajinan Enceng Gondok "Klinting" ini termasuk tenaga kerja yang terampil. Tenaga kerja terampil adalah tenaga kerja yang memiliki keahlian dari pelatihan dan pengalaman kerja membuat kerajinan dari enceng gondok, hal tersebut merupakan suatu wujud dari pada pemenuhan kebutuhan.

Tenaga kerja merupakan orang-orang yang melakukan pekerjaan di suatu perusahaan untuk menghasilkan suatu barang dan orang-orang tersebut sering disebut dengan sebutan karyawan, buruh atau pekerja. Setiap perusahaan, dalam melakukan produksi sebagian besar memiliki pembagian tenaga kerja sesuai dengan kapasitasnya, demikian pula dengan perusahaan Klaster Kerajinan Enceng Gondok "Klinting". Tenaga kerja tetap pada perusahaan ini sejumlah 30 orang dan 30 orang lainnya sebagai tenaga kerja yang dipekerjakan saat order melimpah, demikian total tenaga kerja di perusahaan ini mencapai 60 orang. Pembagian tenaga kerja yang ada di Klaster Kerajinan Enceng Gondok "Klinting" dibagi menjadi empat unit kerja. Berikut tabel unit kerja tersebut:

\section{Tabel 1. Unit kerja Klaster Kerajinan Enceng Gondok "Klinting"}

\begin{tabular}{|c|c|c|c|}
\hline No & Unit Kerja & $\begin{array}{c}\text { Spesifikasi } \\
\text { Bidang }\end{array}$ & $\begin{array}{c}\text { Jumlah } \\
\text { Tenaga } \\
\text { Kerja }\end{array}$ \\
\hline 1 & Administrasi & $\begin{array}{l}\text { Sekretaris I } \\
\text { Sekretaris II } \\
\text { Bendahara I } \\
\text { Bendahara II }\end{array}$ & $\begin{array}{l}1 \text { Orang } \\
1 \text { Orang } \\
1 \text { Orang } \\
1 \text { Orang }\end{array}$ \\
\hline 2 & $\begin{array}{c}\text { Pengadaan } \\
\text { Bahan }\end{array}$ & $\begin{array}{l}\text { Petani } \\
\text { Pencari } \\
\text { Enceng } \\
\text { Gondok } \\
\text { Pengepul } \\
\text { Enceng } \\
\text { Gondok }\end{array}$ & 15 Orang \\
\hline 3 & Produksi & $\begin{array}{l}\text { Desainer } \\
\text { Pembuat } \\
\text { Pola } \\
\text { Penjahit } \\
\text { Penganyam } \\
\text { Bahan } \\
\text { Setengah } \\
\text { Jadi } \\
\text { Penganyam } \\
\text { Barang Jadi } \\
\text { Finishing }\end{array}$ & $\begin{array}{l}1 \text { Orang } \\
1 \text { Orang } \\
1 \text { Orang } \\
100 \text { Orang }\end{array}$ \\
\hline 4 & Pemasaran & $\begin{array}{l}\text { Pemasaran } \\
\text { Produk }\end{array}$ & 10 Orang \\
\hline
\end{tabular}




\section{Pengaruh Terhadap Sumber Daya Manusia}

Penelitian ini dapat diketahui dari beberapa paparan diatas bahwasanya, Klaster Kerajinan Enceng Gondok "Klinting" ini membangun sebuah perusahaan kerajinan tangan yang dapat membantu masyarakat sekitar Rawa Pening agar tetap berfikir kreatif. Cara mengajak masyarakat untuk ikut serta didalam acaraacara yang berhubungan dengan kerajinan tangan, tentu saja hal tersebut harus ada kemauan dari diri sendiri. Namun, kebanyakan masyarakat di sekitar Rawa Pening menjadikan kerajinan tangan yang berbahan dasar dari batang enceng gondok ini sebagai usaha tetap atau hanya sebagai tambahan penghasilan saja. Menurut penulis, perusahaan ini termasuk perusahaan yang berhasil dan mampu menggerakkan masyarakatmasyarakat sekitar untuk mengkomersialkan kerajinan tangan ini. Karena beberapa kali perusahaan juga mengadakan workshop maupun pameran di luar kota juga, salah satunya di Kota Palembang.

\section{KESIMPULAN}

Kerajinan yang dibuat dari media serat alam yaitu enceng gondok ini sangatlah beragam, namun kerajinan dan pelestarian mengenai enceng gondok sangatlah kurang. Karena jika hanya ada bahan baku saja, tetapi tidak ada yang mengontrol tentunya hal yang ingin dicapai tidak akan terealisasikan. Sehingga perlu adanya sumber daya manusia yang cukup dan mampu untuk mengembangkan maupun melestarikannya.

Oleh karena itu, Klaster Kerajinan Enceng Gondok "Klinting" membuat suatu perusahaan yang tersusun dari beberapa kelompok dalam satu organisasi dan terbagi menjadi beberapa unit kerja. Dari hal tersebut dapat diketahui bahwa ada banyak peluang dan pengaruh yang didapatkan dari adanya perusahaan tersebut. Karena perusahaan tersebut bukan hanya sekedar membuat kerajinan tangan yang bermacammacam saja, tetapi perusahaan ini juga sering mengadakan workshop untuk mengajak lebih banyak masyarakat dalam mengembangkan kemampuan membuat kerajinan, perusahaan ini juga sering mengadakan pameran di luar kota seperti salah satunya di Kota Palembang. Dampak lain yang dapat dirasakan dari adanya perusahaan Klaster Kerajinan Enceng Gondok "Klinting" yaitu, masyarakat sekitar Rawa Pening dapat menambah penghasilan dan juga dapat mengurangi adanya dampak buruk dari adanya gulma perairan.

\section{DAFTAR PUSTAKA}

H. B. Sutopo. 2001. Metode Penelitian Kualitatif. Surakarta: Sebelas Maret University Press.

Haryono. 2014. Kerajinan Tangan Enceng Gondok. Semarang: Indonesia Power Unit Bisnis Pembangkit Mrica.

Ivancevich. 2007. Perilaku dan Manajemen Organisasi. Jakarta: Erlangga.

Nobertus Kaleka. 2014. Kerajian Enceng

Gondok. Yogyakarta: Arcita.

James P. Spradley. 2006, Metode Etnografi, Tiara Wacana, Yogyakarta.

Syamsudinnor. 2014. Pengaruh Pemberian Insentif dan Disiplin Kerja Terhadap Kinerja Karyawan Pada PT. Ben Line Agencies (BLA) Banjarmasin. Jurnal STIMI, Vol. 6, No. 1, p. 2 
Arfiati Nurul Komariah / DESKOVI : Art and Design Journal, Vol. 2, No.1, Juni 2019, 5-12

( Halaman ini sengaja dikosongkan) 